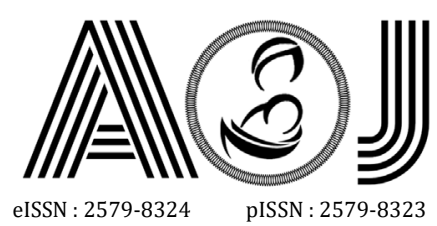

\title{
RESERCH
}

\section{Correlation of Colony Lactobacillus spp. with The Incident of Overactive Bladder with OBSS Score at Pauh Primary Health Center Padang}

Rimbun Wahyu Gumilar ${ }^{1}$, Bobby Indra Utama ${ }^{2}$, Hafni Bachtiar ${ }^{3}$

Affiliation author: 1. Obstetrics and Gynecology, Faculty of Medicine, Andalas University, Chatib Quzwain District Hospital Sarolangun; 2. Sub Division of Urogynecology, Obstetrics and Gynecology Department, Faculty of Medicine, Andalas University, Dr. M. Djamil Central General Hospital Padang; 3. Public Health Department, Faculty of Medicine, Andalas University Padang

Correspondence to: Rimbun Wahyu Gumilar, email: rimbunwahyugumilar@gmail.com, Hp: 081374666642

\begin{abstract}
Background : Overactive bladder (OAB) is a group of urgent symptoms, with or without urgent incontinence. Research shows that some Lactobacillus spp. can be a sign of a women bladder's good health; and found a decrease number of Lactobacillus spp. in patients with OAB. This study aims to assess the correlation of Lactobacillus spp. colony with OAB using the OABSS score at Pauh Primary Health Center, Padang.
\end{abstract}

Method: This research is an analytic study with a cross sectional comparative design. The research was conducted from December 2019 to February 2020 at Pauh Primary Health Center. All women aged 20-40 years who came to Pauh Primary Health Center during the study period were included in the study. Pregnant women, having pelvic abnormalities and a history of other urinary tract diseases or having a history of hypertension and diabetes mellitus were excluded in the study. Numerical data are presented in the form of central tendency. Bivariate analysis was performed using the t-independent test if the data distribution was normal and the Kolmogorov-Smirnov test if the distribution of the data was not normally distributed.

Result: There were 42 samples consisting of 21 OAB respondents and 21 normal respondents. The age of the respondents in the $O A B$ group was $28 \pm 6.8$ years, while the normal group was $32 \pm 7.3$ years $(p>0.05)$. The number of Lactobacillus spp colonies in the normal group was higher than the OAB group, namely 16,389,670 $\pm 74,380,427.9 \mathrm{CU} / \mathrm{ml}$ compared to 15,229,634 $\pm 67,553,932.9 \mathrm{CU} / \mathrm{ml}$ $(p>0.05)$.

Conclusion: There was no correlation between the number of Lactobacillus Spp colonies and the incidence of Overactive Bladder. It is necessary to do further research regarding other risk factors associated with the incidence of $O A B$ and the causes of the decrease number of Lactobacillus spp colonies in $O A B$ patients and the presence of other microorganisms, especially pathogenic microorganisms.

Keywords: overactive bladder, Lactobacillus, OABSS score 


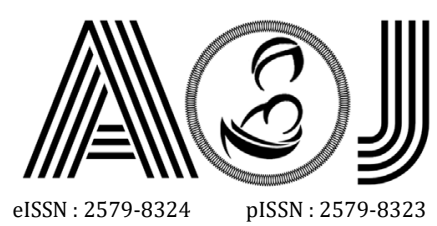

\section{INTRODUCTION}

Overactive bladder (OAB) is a group of urgent symptoms, with or without incontinence urgency usually accompanied with an enhancement frequency of urination and nocturia, as long as there was no infection or other pathological condition. Overactive abladder occurs when the contraction of detrusor muscle did not followed by a maximum volume of urine. This is an inability of the body to adjust to an increasing pressure in the urinal bladder due to increased urine volume.Three a theories of $O A B$ causes were myogenic theory, neurogenic theory and the biological urine itself. ${ }^{1}$

The prevalence of OAB symptoms increases in elderly men and women. ${ }^{2.3}$ Research of Epidemiology of Lower Urinary Tract Symptoms (EPIC) represent subjects aged 40-59 year ( $51 \%$ Men). There were $56 \%$ women that experience symptoms of OAB. ${ }^{3}$ This research took subject samples aged under 39 years old; and the result was $38 \%$ men and $49 \%$ women experienced OAB symptoms. ${ }^{2.3}$

Indonesian urologist did a research of $O A B$ prevalence in Indonesia. The study shows; (1) There was $\geq 20 O A B$ cases per year with most common type was dry OAB (57.4\%), (2) a number of $34.1 \%$ cases need minimal three tool diagnostic to define $O A B$ rate (bladder diary, urinalysis and scoring system). ${ }^{4}$

Some Lactobacillus spp. (for example: Lactobacillus crispatus) could be the marker of a healthy biological urine. It was found least amount of Lactobacillus spp. on patients with OAB. Lactobacillus spp. could protect lower urinary tract through acids which it produced. This will control the growth of virulent bacteria which could notlive in an acid environment. ${ }^{5,6}$

The incident number of overactive bladder $(\mathrm{OAB})$ in patients at Pauh Primary Health Center in Padang was high. Some previous research conducted in Pauh Primary Health Center obtained $97.22 \%$ respondents experienced complaints of overactive bladder. ${ }^{1}$ There were controversies regarding the correlation of Lactobacillus spp. colony with overactive bladder event. This interests us in doing further study regarding the correlation of Lactobacillus spp. colony with overactive bladder (OAB) using OABSS in Pauh Primary Health Center, Padang.

\section{PURPOSE}

This study aims to assess the correlation of Lactobacillus spp. colonies number with the incident of overactive bladder.

\section{METHOD}

This research is an analytic study with a cross sectional comparative design in which dependent and independent variable measured in one time to rate the correlation of Lactobacillus spp. colony number with overactive bladder (OAB) events using OABSS score among group with overactive Bladder (OAB) and a normal group. 


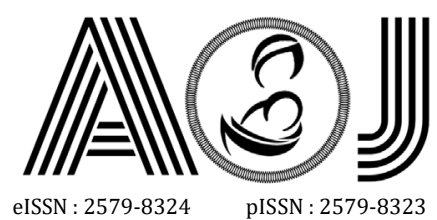

eISSN : 2579-8324
pISSN : 2579-8323

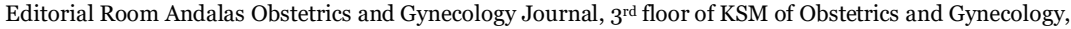

RSUP DR. M. Djamil Padang, Jl. Perintis Kemerdekaan Padang, Sumatera Barat 25127

This research was done by December 2019 to February 2020 in Pauh Primary Health Center Padang. Sample analysis was done in the Microbiology Laboratory of Medical aculty Andalas University Padang. A number of 42 samples taken in a manner of consecutive sampling up to the amount of sample was fulfilled. Women who were not pregnant present with $O A B$ that was found in Pauh Primary Health Center Padang meet the inclusion criteria and did not have exclusion criteria.

Examination by taking history through filling out a validated questionnaire (Overactive Bladder Symptom Score/OABSS) was done. Then, the assessment of clinical symptoms and taking urine sample to examine Lactobacilus colonies and other urine microbiota was conducted.

Before this research began, an ethical clearance was submitted to the Research Ethics Commission Team of the Faculty of Medicine, Andalas University, and had received an ethical clearance statement number 018 / KEP / K / 2020.

\section{RESULTS}

Table 1. Respondent Characteristics

\begin{tabular}{lll}
\hline \multirow{2}{*}{ Variable } & $\begin{array}{l}\text { Overactive Bladder. } \\
(\mathbf{n}=\mathbf{2 1})\end{array}$ & \begin{tabular}{l} 
Normal \\
$(\mathbf{n}=\mathbf{2 1})$ \\
\cline { 2 - 3 }
\end{tabular} \\
\hline Men \pm SD & Men \pm SD \\
\hline $28 \pm 6.8$ & & \\
\hline
\end{tabular}

Based on Table 1, it is known that average age respondents on overactive bladder group was $28 \pm 6.8$ years while on normal group was $32 \pm 7.3$ years. Statistics test indicates there were no difference between the average age among both groups ( $p>0.05)$.

Urinate frequency of normal patients and overactive bladder patients could be seen on Table 2 by the following:

Tble 2. Urinate requency

\begin{tabular}{llll}
\hline Variable & $\begin{array}{l}\text { Overactive Bladder. } \\
(\mathbf{n = 2 1 )} \\
\mathbf{f ( \% )}\end{array}$ & $\begin{array}{l}\text { Normal } \\
\mathbf{( n = 2 1 )} \\
\mathbf{f ( \% )}\end{array}$ & p-value \\
\hline Frequency urinate & & & \\
$-\quad<7$ time & $4(19)$ & $21(100)$ & $<0.001$ \\
$-\quad 8-14$ time & $17(81)$ & $0(0)$ & \\
\hline
\end{tabular}

Based on Table 2 it is known that all (100\%) of normal respondents have urinate frequency of $<7$ time, while in respondents with overactive bladder group, more from half 


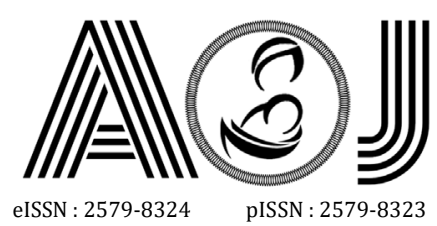

Editorial Room Andalas Obstetrics and Gynecology Journal, $3^{\text {rd }}$ floor of KSM of Obstetrics and Gynecology,

RSUP DR. M. Djamil Padang, Jl. Perintis Kemerdekaan Padang, Sumatera Barat 25127

(81\%) respondents with overactive bladder have urinate frequency of 8-14 time. Statistics test results indicate a correlation among urinate frequency with overactive bladder $(p<0.05)$.

Lactobacillus spp colony numbers on Overactive bladder and normal group could be seen on Table 3 by the following:

Tble 3. Lactobacillus spp. colony number in urine.

\begin{tabular}{lccc}
\hline \multicolumn{1}{c}{ Group } & $\mathbf{n}$ & Men & SD \\
\hline Normal & 21 & $16,389,670$ & $74,380,427.9$ \\
Overactive Bladder & 21 & $15,229,634$ & $67,553,932.9$ \\
\hline
\end{tabular}

Based on Table 3, it is known that Lactobacillus spp colony number in normal group was higher with a number of $16,389,670 \pm 74,380,427.9 \mathrm{CU} / \mathrm{ml}$ while in overactive bladder group has a number of $15,229,634 \pm 67,553,932.9 \mathrm{CU} / \mathrm{ml}$.

Normality test was done using Shapiro-Wilk test and shows weather the data distribution was normal or not. Normality test result could be seen on Table 4 by the following:

Tble 4. Data Normality Test

\begin{tabular}{lllll}
\hline Group & $\mathbf{n}$ & Men & SD & p-value \\
\hline Normal & 21 & $16,389,670$ & $74,380,427.9$ & 0.001 \\
Overactive Bladder & 21 & $15,229,634$ & $67,553,932.9$ & 0.495 \\
\hline
\end{tabular}

Based on the result of normality test, it is known that Lactobacillus spp colony number was not distributed normal and a data transformation needed to be done. After data transformation was done, the result was as following:

Tble 5. Data Normality Test After Data Transformation

\begin{tabular}{lcccc}
\hline \multicolumn{1}{c}{ Group } & $\mathbf{n}$ & Men & SD & p-value \\
\hline Normal & 21 & $16,389,670$ & $74,380,427.9$ & 0.001 \\
Overactive Bladder & 21 & $15,229,634$ & $67,553,932.9$ & 0.495 \\
\hline
\end{tabular}

Data transformation was done and the result obtained was Lactobacillus spp colony number data was not normal. Thus to discover the correlation of the colony number with the incident of overeactive bladder non-parametric statistics test (Kolmogorov-smirnov test) was performed. 


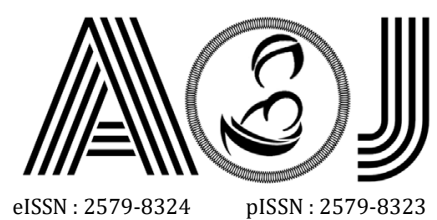

eISSN : 2579-8324
pISSN : 2579-8323
ANDALAS OBSTETRICS AND GYNECOLOGY JOURNAL

Address for Correspondence:

Editorial Room Andalas Obstetrics and Gynecology Journal, $3^{\text {rd }}$ floor of KSM of Obstetrics and Gynecology,

RSUP DR. M. Djamil Padang, Jl. Perintis Kemerdekaan Padang, Sumatera Barat 25127

Website:

http://jurnalobgin.fk.unand.ac.id/index.php/JOE

The correlation of the colony number with the incident of overeactive bladder could be seen on Table 6 , by the following:

Tble 6. Correlation of the colony number with the incident of overeactive bladder

\begin{tabular}{llll}
\hline Variable & $\begin{array}{l}\text { Normal } \\
\text { Men } \pm \text { SD }\end{array}$ & $\begin{array}{l}\text { OB } \\
\text { Men } \pm \text { SD }\end{array}$ & p value \\
\hline $\begin{array}{l}\text { lactobacillus } \\
\text { colony number }\end{array}$ & $16,389,670 \pm 74,380,427.9$ & $15,229,634 \pm 67,553,932.9$ & 0.095 \\
\hline
\end{tabular}

Based on Table 6 it is known that average Lactobacillus spp colony number on normal group was higher than $O A B$ group with a number of $16,389,670 \pm 74,380,427.9 \mathrm{CU} / \mathrm{ml}$ comparable with $15,229,634 \pm 67,553,932.9 \mathrm{CU} / \mathrm{ml}$.

Statistics test resultshowed there were no correlation between the incident of Overactive Bladder with Lactobacillus spp colony number ( $p>0.05)$.

\section{DISCUSSION}

This study resulting that the average amount of Lactobacillus spp number was higher on normal group compared with the $\mathrm{OAB}$ group. This thing shows that overeactive bladder samples have the number of colonies that are lower compared with the without overeactive bladder samples. Based on studies done by Curtiss on 2017 a significant result of $40 \%$ in normal patients and $20 \%$ in $O A B$ patients with $p 0.02$. This thing was parallel with the previous findings in studies by Hilt, et.al which found Lactobacillus $29 \%$ on urine control and $12 \%$ in patients with OAB. Bacteria acid lactate genus Lactobacillus spp. has the characteristics of gram positive, catalase negative, AC ID-tolerant, non spora, womb G. $+C$ low, shape cell rodsorcoccobacilli, aero-tolerant or anaerobic, fastidious.

Lactobacillus could produce metabolites such as organic acids hydrogen peroxide and antimicrobial component such as bacteriocin. Bacteriocin could inhibit pathogenic bacterial growth on fresh meat such Salmonella thypimurium, and Escherichia jerk. Bacteriocin effectiveness compared from Lactobacillus spp. 1223 SCG to Listeria monocytogenes was almost equal with nisin's effectiveness. Salih, et.al explained that acid lactate produced by super natant free cell bacteria that isolated from milk fermentation in Sudan contain antimicrobial component which could inhibit the pathogenic microbial growth such as Staphylococcusaureus, Escherichia jerk and Klebsiella pneumonia. ${ }^{7}$

A number of Lactobacillus spp. able to produce an antimicrobial component called a bacteriocin for example acidoline, acidophylline and lactosidine that is estimated to have a large spectrum compared to grampositive or negative bacteria. ${ }^{8}$ Lactobacillus spp. genus have some advantages in which has the potential to be used as probiotics agents, some of them were able to survive on a low $\mathrm{pH}$, hold on to salt bile, producing antimicrobials and has an 


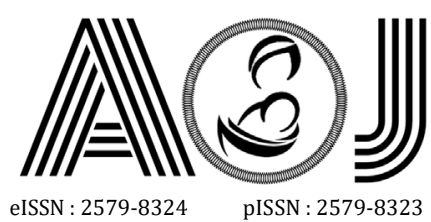

eISSN : 2579-8324
pISSN : 2579-8323

antagonistic power to enteric pathogens, able to assimilate cholesterol serum and to conjugate salt bile and could grow well on medium simple. 9,10

This study shows that the correlation of colonies number with the incident overeactive bladder (OAB). In a healthy person, kidney, ureter (channel from kidney to bladder urine), and free bladder some microorganisms could be found, however bacteria on generally was found on urethra (channel from the bladder to the outside) lower part in men or women. But the numbers reduced in near biological urine, I guess caused by antibacterial effect that launched by the urethral mucus membrane and frequent epithelium rinsed off by the urine. This population characteristic changed according to variations in the menstrual cycle. A main occupant of adults' vagina is Lactobacillus spp. in which tolerant of acid. This bacteria changes glycogen that generated vaginal epithelium, and in thatprocess, produces acid. Glycogen buildup on the wall of vagina was caused by the activity of the ovaries. This thing is not encountered before puberty period or after menopause. As a result of glycogen renovation, vagina's $\mathrm{pH}$ will be around $4.4-4.6 .^{11}$

Lactobacillus spp. and Streptococcus is a genus that most widely reported as urinal microbiota and exist in the whole study that published this moment as an acid lactate bacteria genus that related with some body tissue especially urinary tract where they play a role as aprotector against pathogens. ${ }^{12}$

The correlation between the amount of Lactobacillus spp colony with overactive bladder events with statisticstests done in this study obtained the result was not significant. This events could due by other factor that cause the occurrence of $O A B$ as myocyte damage in the destrusor muscle, damage in inhibitor path in brain and marrow spine or damage insensitivity terminal afferents in biological urinary, UTI, estrogen deficiency and systemic abnormalities.

\section{CONCLUSION}

More than half of normal respondents have urinate frequency of $<7$ times while all overactive bladder (OAB) respondents have urinate frequency of 8-14 times average amount of Lactobacillus Spp colony in normal group was $16,389,670 \pm 74,380,427.9 \mathrm{CU} / \mathrm{ml}$ while in overactive bladder patients (OAB) was 15,229,634 $\pm 67,553,932.9 \mathrm{CU} / \mathrm{ml}$.

There was no correlation between the number of Lactobacillus Spp colonies and the incidence of Overactive Bladder. It is necessary to do further research regarding other risk factors associated with the incidence of $O A B$ and the causes of the decrease in the number of Lactobacillus spp colonies in $O A B$ patients and the presence of other microorganisms, especially pathogenic microorganisms. 


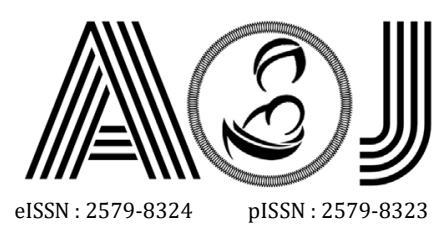

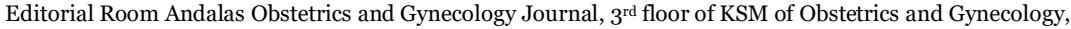
RSUP DR. M. Djamil Padang, Jl. Perintis Kemerdekaan Padang, Sumatera Barat 25127

Website:

http://jurnalobgin.fk.unand.ac.id/index.php/JOE

\section{REERENCES}

1. Junizaf. Book Teach Gynecology. 2003;7-10.

2. Stewart W, Van Rooyen JB, CundiffGW, et al. Prevalenceand burden of overactive bladder in the United States. Worldd J Urol. 2003; 20 (6): 327- 36.

3. Irwin DE, Milsom I, Hunskaar S, et al. Population-based survey of urinary incontinence, overactive bladder, and other lower urinary tract symptoms in five countries: Result of the EPIC study. Eur Urol. 2006; 50: 1306-15pp.

4. Tirtayasa PMW, RahardjoHE. A survey on the management of overactive bladder by Indonesian urologists. Med J Indonesia. 2015; 24 (2): 91-6.

5. Pearce $M M$, Hilt EE, Rosenfeld $A B$, et al. The female urinary microbiome: a comparison of women with and without urgency urinary incontinence. MBio. 2014; 5: e01283314.

6. Thomas-White K, Brady M, Wolfe AJ, et al. The bladder is not sterile: History and current discoveries on the urinary microbiome. CurrBladderDysfunct Rep. 2016; 11 : 18-24.

7. Pearce $M M$, Zilliox $M J$, Rosenfeld $A B$, et al. The female urinary microbiome in urgency urinary incontinence. Am J Obstet Gynecol. 2015; 213: 347.e1-347.e11

8. Khasriya R, Sathiananthamoorthy S, Ismail S, et al. Spectrum of bacterial colonization associated with urothelial cells from patients with chronic lowerurinary tract symptoms. J Clin Microbio. 2013; 51: 2054-62.

9. Karstens $L$, Asquith $\mathrm{M}$, Davin S, et al. Does the urinary microbiomeplay a rolein urgency urinary incontinence and its severity? rontCell Infect Microbiol.2016; 6: 78.

10. Nelson DE, Dong Q, Van Der Pol B, et al. Bacterial Communities of the coronal sulcus and distal urethra of adolescent males. PLoS One. 2012; 7: e36298.

11. Ayres J. Cooperative Microbial Tolerance Behaviors in Host-Microbiota Mutualism. Cell. 2016; 165: 1323-31.

12. Le PT, Pearce MM, Zhang S, Campbell EM, ok CS, Mueller ER, Brincat CA, Wolfe AJ, Brubaker L. IL22 regulates human urothelial cell sensory and innate functions through modulation of the acetylcholine response, immunoregulatory cytokines and antimicrobial peptides: an assessment of an in vitro model. PLoSOne. 2014; 9: e111375. 